\title{
Recovery Potential After Acute Stroke
}

\author{
Rüdiger J. Seitz ${ }^{1,2,3 *}$ and Geoffrey A. Donnan ${ }^{3}$ \\ ${ }^{1}$ Department of Neurology, Centre of Neurology and Neuropsychiatry, LVR-Klinikum Düsseldorf, Heinrich-Heine-University \\ Düsseldorf, Düsseldorf, Germany, ${ }^{2}$ Biomedical Research Centre, Heinrich-Heine-University Düsseldorf, Düsseldorf, Germany, \\ ${ }^{3}$ Florey Institute of Neuroscience and Mental Health, University of Melbourne, Parkville, VIC, Australia
}

In acute stroke, the major factor for recovery is the early use of thrombolysis aimed at arterial recanalization and reperfusion of ischemic brain tissue. Subsequently, neurorehabilitative training critically improves clinical recovery due to augmention of postlesional plasticity. Neuroimaging and electrophysiology studies have revealed that the location and volume of the stroke lesion, the affection of nerve fiber tracts, as well as functional and structural changes in the perilesional tissue and in large-scale bihemispheric networks are relevant biomarkers of post-stroke recovery. However, associated disorders, such as mood disorders, epilepsy, and neurodegenerative diseases, may induce secondary cerebral changes or aggravate the functional deficits and, thereby, compromise the potential for recovery.

Edited by:

Brian Silver,

Alpert Medical School of Brown University, USA

Reviewed by: Bin Jiang, Beijing Neurosurgical Institute, China Roshini Prakash, University of California Los Angeles, USA

${ }^{*}$ Correspondence: Rüdiger J. Seitz seitz@neurologie.uni-duesseldorf.de

Specialty section: This article was submitted to Stroke, a section of the journal Frontiers in Neurology

Received: 27 April 2015 Accepted: 26 October 2015 Published: 11 November 2015

Citation:

Seitz RJ and Donnan GA (2015) Recovery Potential After Acute Stroke.

Front. Neurol. 6:238. doi: 10.3389/fneur.2015.00238 Keywords: cerebral ischemia, infarct location, thrombolysis, recovery, perilesional plasticity, network
reorganization, stroke associated disturbances, neurorehabilitative training

\section{INTRODUCTION}

Stroke is one of the leading causes of persistent disability in Western countries (1). It induces acute deficits of motion, sensation, cognition, and emotion. In the majority of patients, stroke results from an interruption of cerebral blood supply and subsequent ischemic brain damage, while $>25 \%$ of patients suffer from intracranial hemorrhage $(2,3)$. Recovery from stroke is a multifaceted process depending on different mechanisms that become operational at different phases after the acute insult ranging from hours to many months (4). Importantly, intravenous and intra-arterial thrombolyses have opened new avenues to substantially reverse the amount of brain damage and the neurological deficit after stroke (5-8). Furthermore, neuroscience-based strategies in neurorehabilitation have improved the fate of stroke patients. Specifically, training approaches including very early mobilization, antigravity support for walking, basic arm training, and arm ability training can be tailored to the neurological deficits to optimally engage the residual capacities of the patients (9-11). From a technical point of view, neuroimaging and neurophysiological methods have offered means to investigate the recovery potential of stroke patients already in the acute stage of stroke (12-14). In particular, these non-invasive neuroscientific measures substantiate clinical observations and have opened new insights into the neuroscientific basis of recovery mechanisms from stroke. More recently, the recovery potential after stroke has been studied by using multivariate analyses in which epidemiological factors have also been taken into account (15). We address here the mechanisms of post-stroke recovery including postlesional plasticity and disease-related limitations of the recovery potential in acute ischemic stroke. 


\section{MECHANISMS OF POST-STROKE RECOVERY}

\section{Dynamics of Cerebral Ischemia}

A sudden interruption of arterial blood supply leads to disturbances of neural function and the clinical appearance of neurological or neuropsychological deficits. In the most severe cases, ischemia is so severe that structural brain damage and the formation of ischemic brain infarction occur (Figure 1). The cessation of cerebral blood circulation induces an immediate suppression of cerebral electrical activity with peri-infarct depolarization leading to repeated episodes of metabolic stress $(16,17)$. There is good evidence from animal experiments that ischemic damage of neurons and brain tissue occurs in proportion to the reduction of regional cerebral blood flow (rCBF) (16). Thus, the acute occlusion of a cerebral artery, the thereby caused local depression of rCBF, and its subsequent electrical, metabolic, and ionic changes are critical factors determining the extent of a cerebral ischemic infarct (18). Imaging and neurophysiological studies in humans have shown that, similar to animal experiments, spreading depression occurs in severe ischemic stroke leading to progressive infarct expansion $(19,20)$.

After occlusion of a cerebral artery, an area of impaired perfusion surrounds an area with a complete cessation of perfusion whose extent is determined by the compensatory recruitment of arterial collaterals. In the area of misery perfusion, the so-called penumbra, the extraction of oxygen from blood into brain tissue is enhanced as was shown in stroke patients by multiparametric imaging with positron emission tomography $(21,22)$. The advent of magnetic resonance imaging (MRI) has allowed a spatial dimension to be introduced. It has been shown that the area of impaired perfusion typically exceeds the area of reduced extracellular water diffusion, thus signifying virtually reversible brain tissue damage due to ischemia (23-25). In fact, there is a good correspondence between the area with enhanced oxygen extraction and the perfusion-diffusion mismatch area in acute stroke $(26,27)$.

The area of reduced brain perfusion undergoes a dynamic lesion transformation within the first $24 \mathrm{~h}$ after onset of ischemia

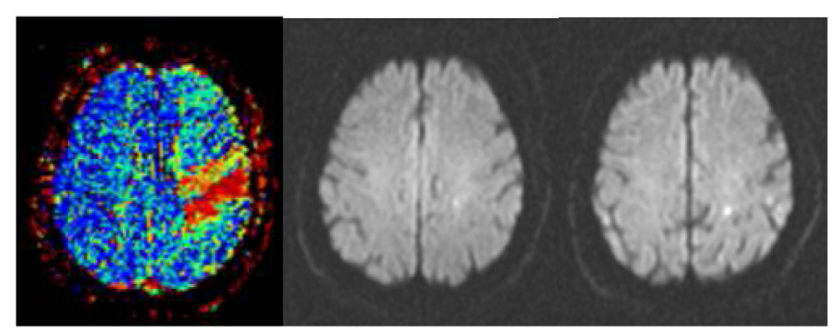

FIGURE 1 | Successful thrombolysis. (Left) Severe perfusion deficit in the precentral gyrus (red) as assessed in a time-to-peak map before thrombolysis. (Middle) Point-like abnormality in diffusion-weighted imaging at the same time signifying the perfusion-diffusion mismatch. (Right) Two small lesions in diffusion-weighted imaging $24 \mathrm{~h}$ after intravenous thrombolysis accompanied by complete recovery from hemiparesis.
(28-30). In a persisting arterial occlusion, the infarct lesion expands up to $24 \mathrm{~h}(31,32)$. Beyond the acute time window of about $24 \mathrm{~h}$, secondary changes including an early phase with vasogenic edema and a later phase with inflammatory infiltration evolve (33-35). Lymphocytes and macrophages have been shown to accumulate in the perivascular vicinity $\sim 6$ days after a cerebral infarction and are heterogeneously distributed within the infarct area (36). Due to their immunological competence, these cells are suited to augment the infarct lesion raising the interesting notion that immunosuppression may have a beneficial affect in acute stroke (37).

\section{Reversal of Cerebral Ischemia}

In acute ischemic stroke, intravenous thrombolysis is targeted toward the rescue of brain tissue by early recanalization of the occluded cerebral artery. It has been shown to be effective up to $4.5 \mathrm{~h}$ with maximal efficacy within the first $90 \mathrm{~min}$ after symptom onset $(5,6,38)$. The beneficial role of early recanalization was demonstrated by functional brain imaging (39-42) and monitoring with transcranial Doppler sonography $(43,44)$. More recently, neuroradiological interventions with intra-arterial thrombolysis and/or thrombectomy have been shown to be at least as effective as intravenous thrombolysis even in distal carotid or proximal middle cerebral artery (MCA) occlusion (8). By multiparametric MRI, it became evident that brain tissue at the risk of ischemic damage can be salvaged by tissue reperfusion (Figure 1). Important factors determining the extent of a brain infarct are the severity and duration of ischemia, the dimension and composition of the causal arterial emboli, the anatomy and the vascular changes of the cerebral arteries, and the presence of diabetic hyperglycemia $(29,41,45-47)$. In failed reperfusion, severe edema formation will develop that can hardly be limited pharmacologically. Thus, to rescue patients from malignant brain swelling after stroke craniectomy has been advocated as a symptomatic therapy which is a life-saving action but does not reduce the neurological deficit in patients older than 60 years (48).

Brain infarcts may result from cardiac or artery to artery embolism, from thrombotic occlusion of the small penetrating arteries complicating vessel hyalinosis or microatheroma (49, 50). While infarcts in the territory of the posterior cerebral artery (PCA) are typically embolic in origin affecting the entire supply area of the PCA (51), infarcts in the anterior cerebral artery (ACA) territory are usually of atherosclerotic origin and more variable in lesion pattern and neurological deficit (52). The situation is most complex in the MCA territory because of the arborization of the MCA, the large territory supplied by the artery, and the widespread anastomoses of the leptomeningeal arterial branches fed from the ACA or PCA. The poorer these collaterals are due to arterosclerotic changes in the intracranial arteries, the more severe is the initial ischemic event and the resulting stroke lesion $(41,53,54)$.

The location and the volume of the cerebral infarct determine the neurological deficit in an individual patient as shown for sensorimotor as well as cognitive and emotional functions (55-61). Large brain infarcts involving subcortical white matter may affect multiple brain systems which may result in complex neurological syndromes, such as apraxia, neglect, 
and Gerstman's syndrome (62-64). In such patients, measures of fiber tract damage or cortical activations have been found to predict the degree of recovery $(55,65-68)$. Similar observations have also been made for language, somatosensory and visual functions (69-72).

\section{Residual Brain Infarct Lesions After Thrombolysis}

The successful recanalizing therapy is of fundamental importance for the topography and volume of the resulting ischemic infarct lesion $(73,74)$. This was taken into consideration in developing a refined classification of ischemic brain infarcts (75). It should be stated, however, that the functional prognosis of ischemic stroke is worse than that in cerebral hemorrhage in stroke survivors (76). This most likely reflects the structural damage of brain tissue in ischemic stroke, while in cerebral hemorrhage recovery can occur largely upon absorption of the hematoma. Accordingly, territorial Type I infarcts depend on the size of the emboli and the location of the arterial occlusion (Table 1). Distal arterial branch occlusion gives rise to small infarcts entirely limited to the cerebral cortex, while proximal arterial branch occlusions result in larger infarcts involving the cerebral cortex and the underlying

\begin{tabular}{|c|c|c|c|}
\hline Type & Infarct location & Pathogenesis & $\begin{array}{l}\text { Response to } \\
\text { thrombolysis }\end{array}$ \\
\hline I & Territorial & $\begin{array}{l}\text { Occlusion of cerebral } \\
\text { artery branch }\end{array}$ & \\
\hline I.1 & Cortical & Distal branch & Early \\
\hline 1.2 & Cortico-subcortical & Proximal branch & Limited \\
\hline II & Striatocapsular & Occlusion of MCA stem & \\
\hline II.1 & \pm Insula & Infarct core & Early \\
\hline II.2 & $\begin{array}{l}\text { +Periventricular } \\
\text { white matter }\end{array}$ & Large lesion & Limited \\
\hline III & & $\begin{array}{l}\text { Lacunar hyalinosis of } \\
\text { arterioles }\end{array}$ & Limited \\
\hline III. 1 & Fiber tracts & & \\
\hline III.2 & $\begin{array}{l}\text { Internal capsule } \\
\text { (anterior choroidal } \\
\text { artery) }\end{array}$ & & \\
\hline III.3 & $\begin{array}{l}\text { Basal ganglia, lateral } \\
\text { thalamus }\end{array}$ & & \\
\hline III.4 & $\begin{array}{l}\text { Medial and anterior } \\
\text { thalamus (perforating } \\
\text { branches of posterior } \\
\text { cerebral artery) }\end{array}$ & & \\
\hline IV & & $\begin{array}{l}\text { Chronic hemodynamic } \\
\text { deficit + downstream } \\
\text { emboli }\end{array}$ & \\
\hline IV.1 & Cortico-subcortical & $\begin{array}{l}\text { Extracranial artery } \\
\text { occlusion } \pm \text { intracranial } \\
\text { large artery } \\
\text { occlusion } \pm \text { accompanied by } \\
\text { reactive vasodilation }\end{array}$ & Limited \\
\hline IV.2 & Arterial borderzone & Extracranial artery occlusion & \\
\hline
\end{tabular}

Adapted from Seitz and Donnan (75). white matter $(77,78)$. In MCA stroke, these territorial infarcts do not destroy the entire motor and somatosensory representation areas, nor the complete descending motor cortical output or afferent sensory input tracts $(55,79,80)$. This allows sufficient recovery potential associated with perilesional reorganization in the adjacent cerebral tissue in response to various neurorehabilitative approaches.

Ischemic lesions of large parts of or the entire striatocapsular region typically result from an embolic occlusion of the MCA stem (81) (Table 1). If reperfusion is achieved early, only the deep perforating arteries and the arteries that supply the insular cortex may remain obstructed causing infarcts of the lentiform nucleus and insula (82). However, when collaterals are insufficient due to arteriosclerotic changes in multiple cerebral arteries $(41,53,54)$, the infarct lesions become larger involving to a larger extent also the hemispheric white matter. This causes hemispatial neglect and conduction aphasia due to cortico-cortical and corticosubcortical disconnections $(62,83,84)$.

Small-sized, lacunar-type, infarcts (Type III infarcts) result from an occlusion of the small penetrating cerebral arteries or even arterioles. They typically occur in the anterior choroidal artery, the deep perforating lenticular MCA branches, the thalamic branches of the PCA, or in brainstem structures and the pons $(85,86)$. In spite of their small spatial dimension, but due to their strategic location, they cause well-defined neurological syndromes, such as pure motor and pure sensory stroke (Table 1). These infarcts have a limited recovery potential as predicted by a loss of motor-evoked potentials and asymmetry of water diffusivity on MR imaging $(55,87,88)$. The crucial role of the white matter for functional outcome becomes apparent from the observation that small infarcts in the precentral gyrus allow for profound motor recovery, whereas infarcts of similar volume in the periventricular white matter or the internal capsule may induce a severe and persistent hemiparesis $(89,90)$. Interestingly, white matter damage in stroke was found in a large genome-wide association study to be related to a mutation in chromosome 17 (91).

Patients with a chronic occlusion of extracranial cerebral arteries resulting from dissection or long-standing cerebrovascular disease constitute Type IV infarcts (Table 1). These patients may become symptomatic with transient ischemic attacks due to small embolic or hemodynamically induced watershed infarcts in cerebral white matter $(92,93)$. In these patients, blood flow depression induces a reactive vasodilatation of the intracranial blood vessels resulting in a severe delay in cerebral brain perfusion in the presence of an enhanced cerebral blood volume $(94,95)$.

\section{Perilesional Plasticity}

Ischemia and reperfusion evoke a large number of biochemical, metabolic, and immunological processes that evolve sequentially as identified in animal experiments (96). In addition, there are rapid changes in the expression of genes, neurotransmitters, such as glutamate and GABA, as well as neurotrophic mediators implicated as molecular substrates related to perilesional reorganization $(21,97-101)$. These biochemical changes are accompanied on the microscopical level by the growing of axons 
and formation of new synapses in the perilesional vicinity and in remote locations in functionally related areas in the affected and contralesional "non-affected" hemisphere $(102,103)$. In particular, they occur when animals recover in an enriched environment or are subjected to dedicated training $(104,105)$.

Non-invasive brain stimulation techniques have provided means to explore changes of cortical excitability following stroke in humans. There are different technical approaches that allow to enhance or to suppress brain activity (106). By these methods, diagnostic and therapeutic goals were aimed for as summarized in Table 2. For example, using paired-pulse TMS, it was found that within the first 7 days after a brain infarct, there is an enhanced cortical excitability in the cortex adjacent to the brain lesion (107-109). In fact, the sites of residual motor representation move into the region of maximal cortical disinhibition (110). Also, fMRI activation areas related to finger movements were found to remap to spared more dorsal locations of the motor cortex (111, 112). Notably, an enhanced excitability was propagated to the contralesional hemisphere $(14,107-109,113)$. It decreased in the patients who showed a good recovery within the 90 days, while it persisted in those patients with poor recovery (114). In keeping with these observations, functional MRI performed $\sim 2$ days after stroke revealed an area in the ipsilesional postcentral gyrus and posterior cingulate gyrus that correlated with motor recovery $\sim 3$ months after stroke (115). Conversely, recovery of hand function was associated with progressively lateralized activation of the affected sensorimotor cortex (116-118).

Non-invasive electrical anodal stimulation of the affected motor cortex was found to augment motor skill acquisition due to improved consolidation but not due to long-term retention of the task (120). In contrast, application of $1-\mathrm{Hz}$ repetitive TMS (rTMS) that downregulates the contralesional motor cortex improved the kinematics of finger and grasp movements in the affected hand (121). This was accompanied by an overactivity in the contralesional motor and premotor cortical areas predicting improvement in movement kinematics. One may wonder if longterm retention of the induced effects can be achieved by longer lasting stimulation or by the combination of voluntary action and direct brain stimulation preferentially in the acute phase after stroke. The combination of electrical stimulation of finger extensor muscles and training over $2-3$ weeks did not result in a greater improvement of dexterity of the affected hand as assessed with the Jebson test than each intervention alone (122). Subjects with an intact motor cortex showed a greater improvement than those who had damage of the motor cortex. Similarly, in chronic stroke-induced aphasia rTMS over the left inferior frontal gyrus resulted in an increase of reaction time or error rate in a semantic task suggesting restoration of a perilesional tissue in the left hemisphere after stroke $(123,124)$. Given the human postlesional changes of cortical excitability it may be intriguing to rebalance the interhemispheric rivalry by direct cortical stimulation or peripheral stimulation (125-128). An even greater effect was observed when bihemispheric direct cortical stimulation was used to activate the affected motor cortex and to inhibit the contralesional motor cortex (129). Cortical stimulation in association with motor training also improved motor performance $(128,130-132)$. Along the same line, combining peripheral nerve stimulation to the affected hand with anodal direct current stimulation of the affected motor cortex in chronic stroke facilitates motor performance beyond levels reached with either intervention alone (133).

\section{Infarct Induced Damage to Cortico- Cortical and Cortico-Subcortical Connections}

Corticospinal fibers are key factors for the recovery of motor function after stroke as demonstrated with different imaging modalities as well as electrophysiological measures $(55,87$, 134-136). In non-human primates, the cortico-reticulo-spinal and cortico-rubro-spinal tracts are known to mediate motor functions in case of corticospinal tract lesions $(137,138)$, since these tracts have been described as functionally redundant in healthy animals (139). In humans, however the corticospinal tract is of key relevance for motor recovery (Figure 2). In fact, the integrity of the corticospinal tract determines the movement related motor cortex activation $(65,87)$. When there are no motor evoked potentials and there is poor recovery in chronic patients, the fractional anisotropy of the posterior part of the internal capsule as assessed by diffusion tensor imaging was altered in the affected hemisphere $(68,87)$. Notably, these patients had bilateral fMRI activations in relation to finger movements, while in the patients with a lower asymmetry, there was an activation lateralized to the affected hemisphere.

There are not only changes in the efferent motor fiber tracts but also in the cortico-cortical and probably also cortico-subcortical fiber tract systems during recovery. In fact, the intracortical excitability as assessed with TMS was increased in motor cortex of

TABLE 2 | Techniques, actions, and effects of non-invasive stimulation of the human brain.

\begin{tabular}{|c|c|c|c|c|c|c|}
\hline \multicolumn{4}{|c|}{ Transcranial magnetic stimulation (TMS) } & \multicolumn{3}{|c|}{ Transcranial electrical stimulation } \\
\hline & & & & uromodulatory effects & & \\
\hline \multirow[t]{3}{*}{ Single pulse TMS } & Paired-pulse TMS & Repetitive TMS & Patterned rTMS & $\begin{array}{l}\text { Direct current stimulation } \\
\text { tDCS }\end{array}$ & $\begin{array}{l}\text { Alternating current } \\
\text { stimulation }\end{array}$ & $\begin{array}{l}\text { Random noise } \\
\text { stimulation }\end{array}$ \\
\hline & $\begin{array}{l}\text { Intracortical (single } \\
\text { coil) }\end{array}$ & $\begin{array}{l}1 \mathrm{~Hz} \text { TMS } \\
\text { (inhibitory) }\end{array}$ & $\begin{array}{l}\text { Continuous theta-burst } \\
\text { stimulation (inhibitory) }\end{array}$ & Cathodal tDCS & & \\
\hline & $\begin{array}{l}\text { Cortico-cortical (two } \\
\text { coils) }\end{array}$ & $\begin{array}{l}>4 \mathrm{~Hz} \text { TMS } \\
\text { (excitatory) }\end{array}$ & $\begin{array}{l}\text { Intermittent theta-burst } \\
\text { stimulation (excitatory) }\end{array}$ & Anodal tDCS & & \\
\hline
\end{tabular}

After Liew et al. (119). 


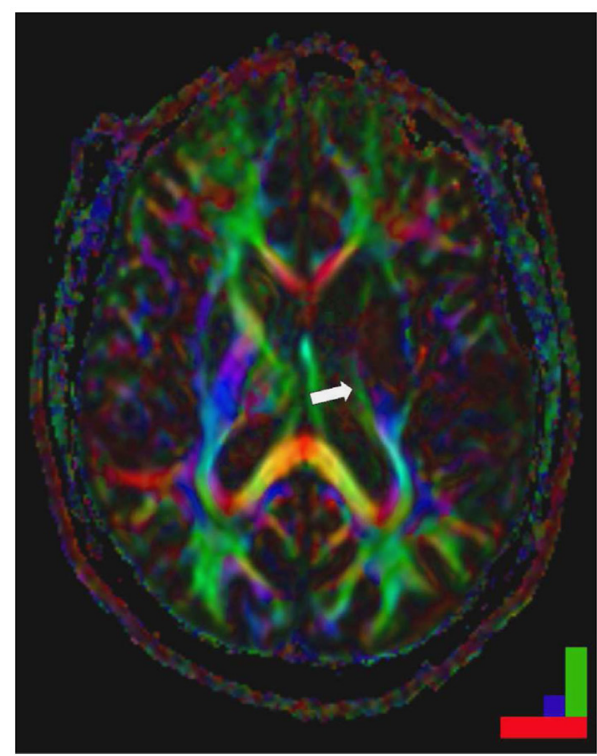

FIGURE 2 | Striatocapsular stroke (Type II.1) in a patient with persistent hemiplegia. Note the small but complete destruction of the posterior limb of the internal capsule (arrow). Color bar: green fronto-occipital diffusion, red right-left diffusion, blue dorso-ventral diffusion. By permission of Oxford University Press (URL www.oup.com), Free permission Author reusing own material, p. 82 fig: 6.4 (left part) from "Stroke Rehabilitation" edited by Carey and Leeanne (140)

both hemispheres both in subcortical and cortical infarcts (108, $114,141,142)$. Conversely, ipsilesional MEPs were more easily elicited from proximal muscles in stroke patients than in healthy subjects (143-145). Moreover, motor cortical connectivity was shown by diffusion tensor imaging to be enhanced after stroke (146). Additionally, orientation uncertainty and greater white matter complexity correlated with functional outcome and were possibly triggered by functional demands $(146,147)$. In addition, it was found recently that the pyramidal tract splits up in the pons forming a ventral and a dorsal tract. When both tracts are affected, patients have a poor recovery, while continuity of the projections in the dorsal portion was characterized by good recovery (136). In addition, in chronic stroke patients, DTI-derived measures of transcallosal motor fibers as well as ipsilesional corticospinal tracts pyramidal tract and alternate fiber tract determine the therapeutic response to rehabilitation. The more the diffusivity profiles resembled those observed in healthy subjects, the greater a patient's potential for functional recovery (88). These findings accord with the evidence from functional imaging suggesting that the concerted action of both cerebral hemispheres is required for recovery. This corresponds well to the observation that even patients with an excellent recovery may show a bilateral activation pattern $(148,149)$. This abnormal activity involved premotor cortical areas and was largely reminiscent of activity patterns in learning but are essentially transient in nature $(84,115,149)$. Notably, tiny activation areas in contralesional motor cortex were related to mirror movements that frequently occur initially after stroke (150).
Network types of neuroimging data analysis have revealed that there is a pathological interhemispheric interaction between the ipsi- and contralesional motor cortex as well as between the ipsilesional supplementary motor area (SMA) and contralesional motor cortex in patients with a single infarct lesion $(151,152)$. In unilateral movements of the affected hand, there was an inhibitory influence from the contralesional to the ipsilesional motor cortex which correlated with the degree of motor impairment (152). In bimanual movements, the interaction of the ipsilesional SMA and the contralesional motor cortex was reduced, and this correlated with impaired bimanual performance. This can be related to the observation that there was less activation in contralesional motor cortex when the motor task did not require working memory demands and no change when the task required online visual feedback monitoring (153). Furthermore, connectivity strength of the prefrontal cortex to the premotor cortex was enhanced in relation to motor imagery highlighting its role for higher order planning of movement (154).

\section{DISEASE-RELATED LIMITATIONS OF THE RECOVERY POTENTIAL}

\section{Associated Diseases}

It has been known for 30 years that patients with acute stroke may develop cognitive impairment and mood disorders which may aggravate their clinical conditions $(155,156)$. However, only recently it was shown in a large database of stroke patients subjected to systemic thrombolysis that the pre-existing functional impairment may reduce the patients' response to thrombolysis and the survival rate (157). In a prospective, open label study of 192 patients ( $68 \pm 13$ years, $50 \%$ males) subjected to intravenous thrombolysis the patients was found to improve $(P<0.0001)$, while $18 \%$ deceased within 100 days (158). This was predicted by older age $(76 \pm 10$ years, $P<0.05)$ and more severe affection on admission $(P<0.0001)$. Also, these patients more frequently had atrial fibrillation $(P<0.03)$ than the surviving patients. Furthermore, it was found that stroke patients with a severe prestroke disability have a virtually $50 \%$ risk of deceasing. It seems that women are particularly liable of depression after stroke and that this is related to a greater stroke severity (159). Of note are patients with migraine that to a large proportion suffer from small vessel disease (160) or hemorraghic stroke (161). This is of great functional relevance since white matter disease due to small vessel disease enhances the risk of depression, physical disability, and a reduction of quality of life (162). Furthermore, there is evidence from a huge meta-analysis that ischemic stroke is associated with the presence and subsequent development of dementia, particularly in recurring ischemic stroke (163). In addition, dementia was found to be associated with increased letality (164). Interestingly, small vessel disease is the most frequent vascular abnormality in patients with Parkinson's disease $(165,166)$. These vascular changes seem to predispose patients with Parkinson's disease to cerebrovascular accidents (167). Arteriosclerosis was found to be of particular relevance for Parkinsonian gait, while macroscopical infarcts seem to result in rigidity (168). Moreover, infarcts induce epileptic seizures (169), which may mimic stroke as in 
Todd's paresis and impair recovery due to reduced consciousness. Beyond that stroke may induce changes of affect including alexithymia (58) or depression (170). The latter was found to be most severe in chronic obstructive pulmonary disease, smoking, and in patients with poor socioeconomic status. Also the increasing lesion load with recurrent strokes in the elderly may predispose to depression (171) and death (172). Thus, there is an intimate interaction of stroke and comorbities the latter of which impair the recovery potential of stroke patients. Deeper insight into the pathophysiology of these interactions is required to counteract these detrimental effects and to enhance the recovery potential of the multimorbid stroke patients.

\section{Functional Deficits in Brain Infarcts}

The neurological deficit has two expressions. There is the impairment to perform actions on command which is usually assessed in clinical examinations. And there is the decrease in spontaneous motor activity which may be functionally relevant (Figure 3 ). In a prospective study of 25 patients ( $63 \pm 10$ years) with acute MCA stroke and seven control patients without neurological disease (61 \pm 14 years), movement activity was measured continuously for 4 days in both arms using Actiwatches (Cambridge Research Instruments, UK). Stroke patients with an initial decline in arm movement activity showed no increase in movement activity in either arm over 4 days after stroke, while other patients improved steadily after admission. The impairment continued to be different among the two groups 3 months after stroke (173). Stroke severity, location and treatment, as well as arterial blood pressure and body temperature were not different among the groups. But, in the non-recovering patients, the C-reactive protein was elevated and related to a low number of waking hours. These results support the notion that in the acute stage after MCA stroke, there are patients with a secondary decline in general motor activity and an enhanced sleep demand which was related to systemic inflammation.

Moreover, recordings with the electroencephalogram (EEG) revealed that stroke patients may exhibit focal slow wave activity (SWA) as well as focal epileptic changes in the affected hemisphere (175-177). Focal SWA (1-4 Hz) has been reported to predict poor recovery from stroke (178-180) but can last even for years (181). Notably, EEG recordings have revealed that, in addition to their neurological deficit, stroke patients also have
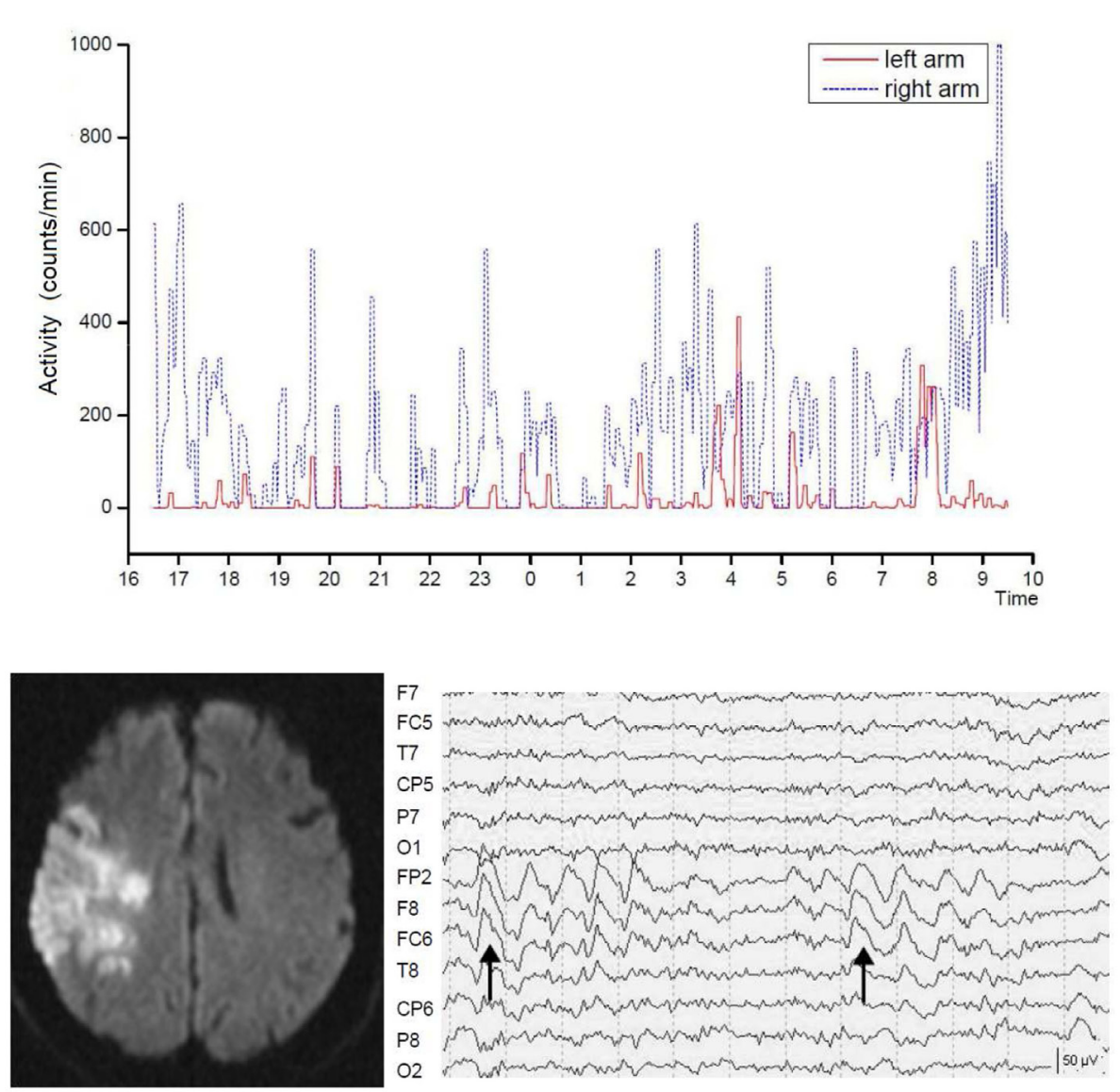

FIGURE 3 | Severely reduced spontaneous movement activity in the affected left arm in right hemispheric brain infarct. Shown is the recording time between 4 p.m. until 10 a.m. the following day. The intermittent slow wave activity in electroencephalographic recordings predicted poor motor recovery. Dotted lines indicate seconds. From Ruan and Seitz (174). 


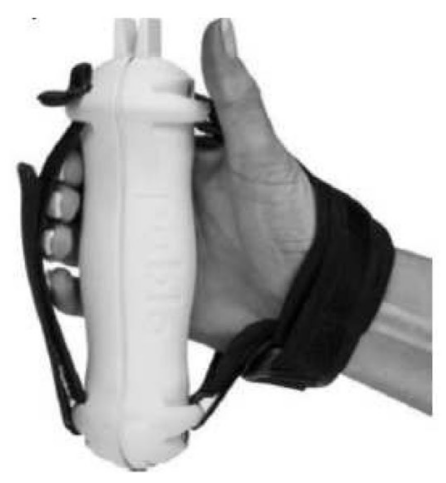

Stroke Patients, affected hand rotation

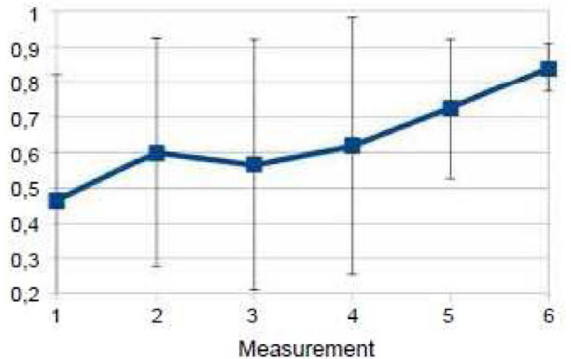

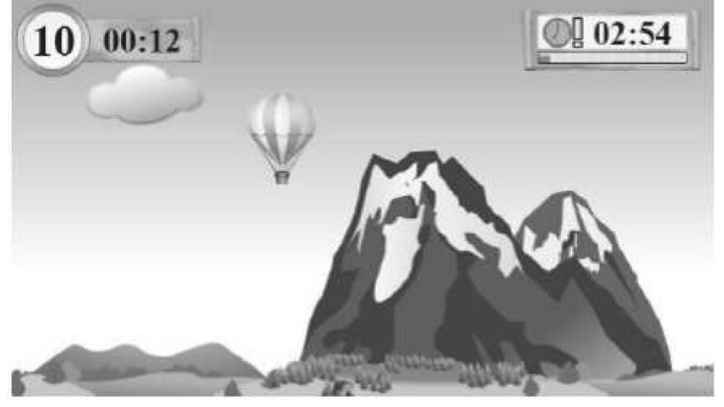

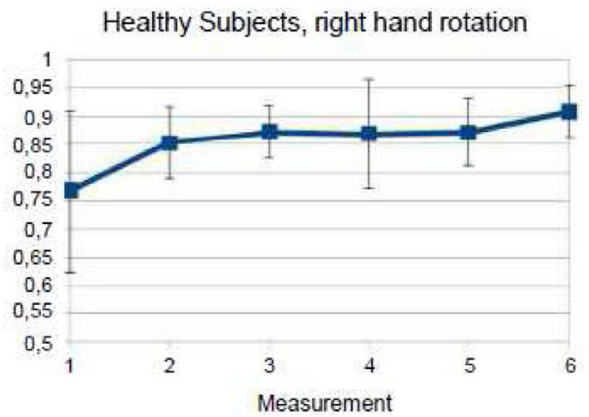

FIGURE 4 | Gaming-based training scenario using the commercially available hand hold PABLOR-device. Hand movements are measured by acceleration and force sensors and thereby steer objects in virtual reality games. Training on consecutive days enlarged the angle of hand rotations and decreased the heterogeneity of movement execution both in healthy subjects and stroke patients. From Seitz et al. (213).

an abnormal sleep architecture $(182,183)$. It is unclear, however, what the functional impact of SWA is on spontaneous movement activity of the affected side after stroke. In fact, stroke patients with similar infarcts concerning lesion location and volume may show recovery patterns of the formal neurological assessment that are not reflected by the spontaneous movement activity of the affected limbs $(184,185)$. In acute stroke patients ( $68 \pm 8$ years $)$ and age-matched controls ( $68 \pm 12$ years), movement activity was measured continuously and synchronously with the EEG for $24 \mathrm{~h}$ in both arms using actiwatches (174). The stroke patients had lower total sleep time $(P=0.031)$, sleep efficiency $(P=0.019)$, percent non-rapid eyement movement sleep $(P=0.034)$, and percent sleep stage N2 $(P=0.003)$ and showed reduced spontaneous movement activity in the affected arm during wakefulness. Stroke patients with abnormal focal SWA showed less spontaneous arm movement activity than those without SWA, while there were no differences in the sleep parameters (Figure 3). These findings accord with earlier observations by Bassetti and Aldrich (175) supporting the notion that sleep architecture is impaired in stroke patients leading to sleep fragmentation, increased wakefulness, and increased REM latency (186). Furthermore, the stroke patients with SWAs enjoyed a limited recovery as assessed with the NIHSS. Thus, focal SWA is a marker of profound brain pathology.

\section{Times-Lines for Post-Stroke Recovery}

The neurological deficits can regress substantially in the early period after ischemic stroke following acute stroke treatment with arterial recanalization and effective reperfusion. The relatively early recovery in patients with small cortical lesions steadily evolves over weeks and levels out over the subsequent months $(112,187,188)$. In contrast, the processes of cerebral reorganization are slow and may need many months to complete. In the acute phase of stroke, it is difficult to predict the degree of ultimate recovery, since there is a large heterogeneity of recovery over the first 3 months after stroke (12). Prediction becomes progressively better the more specific and differentiated the physiological assessment measures are and the longer the time since stroke $(70,189,190)$. For example, the neurological state by day 4 predicts the long-term neurological outcome $(188,191)$. The recovery of activities of daily living usually develop within 26 weeks after the stroke insult and is often accompanied by compensatory hand use $(192,193)$.

\section{Neurorehabilitative Training}

There are numerous reports about rehabilitative approaches to improve the neurological deficit following stroke $(4,13)$. Notably, patients older than 65 years benefit as much as younger patients from intensive rehabilitation $(190,194)$, while younger patients typically improve more on mobility, balance, walking, and grip strength (195). The intensity of the training rather than the type of training appears to determine long-term improvement of motor function $(113,196-198)$. While passive training of wrist movements was reported to be clinically effective and associated with change in cortical activation (199), volitional control of finger and thumb extensions was found to play an important role 
for successful hand shaping and grasping of objects $(147,214)$. Importantly, repetitive training of the affected arm resulted in an increase of activation in the sensorimotor cortex related to hand movements which initially persisted for weeks after training completion and then decreased in magnitude in relation to the functional gain $(200,201)$. In contrast, mirror therapy was found to improve the neurological status immediately after the intervention and to be effective even at long-term follow-up (202, 203).

Training of the affected limb as well as training targeting the non-affected limb has been proposed to be effective. For example, use of bilateral synergies has been reported to improve the motor capacity of the paretic arm (204). It was described that active-passive bilateral arm therapy can produce sustained improvements in upper limb motor function in chronic stroke patients. This was paralleled by an enhanced ipsilesional motor cortex excitability and an increased transcallosal inhibition from ipsilesional to contralesional motor cortex (205). Conversely, the concept of "learned non-use" was implemented in new approaches of rehabilitative strategies in chronic patients with brain infarction (206, 207). This therapy has been shown to be successful even when applied in the chronic state to moderately affected patients (65, 208, 209). This beneficial effect of constraint-induced movement therapy is likely to be composed of focusing the patient's attention to the affected side and imposing repetitive training. It was shown

\section{REFERENCES}

1. Bejot Y, Benatru I, Rouaud O, Fromont A, Besancenot JP, Moreau T, et al. Epidemiology of stroke in Europe: geographic and environmental differences. J Neurol Sci (2007) 262:85-8. doi:10.1016/j.jns.2007.06.025

2. Intiso D, Stampatore P, Zarrelli MM, Guerra GL, Arpaia G, Simone P, et al. Incidence of first-ever ischemic and hemorrhagic stroke in a well-defined community of southern Italy, 1993-1995. Eur J Neurol (2003) 10:559-65. doi:10.1046/j.1468-1331.2003.00648.x

3. Shiber JR, Fontane E, Adewale A. Stroke registry: hemorrhagic vs. ischemic strokes. Am J Emerg Med (2010) 28:331-3. doi:10.1016/j.ajem.2008.10.026

4. Carey LM, Seitz RJ. Functional neuroimaging in stroke recovery and neurorehabilitation: conceptual issues and perspectives. Int J Stroke (2007) 2:245-64. doi:10.1111/j.1747-4949.2007.00164.x

5. Hacke W, Donnan G, Fieschi C, Kaste M, von Kummer R, Broderick JP, et al. Association of outcome with early stroke treatment: pooled analysis of ATLANTIS, ECASS, and NINDS rt-PA stroke trials. Lancet (2004) 363:768-74. doi:10.1016/S0140-6736(04)15692-4

6. Hacke W, Kaste M, Bluhmki E, Brozman M, Dávalos A, Guidetti D, et al. Thrombolysis with alteplase 3 to 4.5 hours after acute ischemic stroke. $N$ Engl J Med (2008) 359:1317-29. doi:10.1056/NEJMoa0804656

7. Donnan GA, Baron JC, Ma M, Davis SM. Penumbral selection of patients for trials of acute stroke therapy. Lancet Neurol (2009) 8:261-9. doi:10.1016/ S1474-4422(09)70041-9

8. Berkhemer OA, Fransen PS, Beumer D, van den Berg LA, Lingsma HF, Yoo AJ, et al. A randomized trial of intraarterial treatment for acute ischemic stroke. N Engl J Med (2015) 372:11-20. doi:10.1056/NEJMoa1411587

9. Cumming TB, Thrift AG, Collier JM, Donnan G, Bernhardt J. An early mobilization protocol successfully delivers more and earlier therapy to acute stroke patients: further results from phase II of AVERT. Stroke (2011) 42:153-8. doi:10.1161/STROKEAHA.110.594598

10. Hesse S. Treadmill training with partial body weight support after stroke: a review. NeuroRehabilitation (2008) 23:55-65.

11. Platz T, van Kaick S, Mehrholz J, Leidner O, Eickhoff C, Pohl M. Best conventional therapy versus modular impairment-oriented training for arm paresis after stroke: a single-blind, multicenter randomized controlled trial. NeurorehabilNeuralRepair(2009)23:706-16.doi:10.1177/1545968309335974 to result in improved motor function and enhanced activation in the partially damaged sensorimotor cortex and other gray matter areas including the hippocampus (210).

Recently, computer-based training approaches employing virtual realitiy scenarios have been developed for neurorehabilitative training purposes, since it was assumed that they engage the patients emotionally and thereby enhance their inclination to embrace rehabilitation training activities. For example, the rehabilitation gaming system (RGS) is a flexible, virtual realitybased device for rehabilitation of neurological patients (211). In fact, it was shown to effectively improve arm function in acute and chronic stroke patients. Furthermore, it was shown by fMRI that the RGS engages human mirror neuron mechanisms that underly visuomotor coordination (212). Similarly, the handhold multifunctional $\mathrm{PABLO}^{\mathrm{R}}$-device was applied for the training of visuomotor-tracking paradigms. It was observed that training of the right dominant hand improved visuomotor coordination of hand rotation movements in both hands in healthy subjects. Notably, it was successful only in the trained hand in stroke patients (Figure 4). Since these gaming applications capitalize on the positive affect of the patients and engage brain structures known to be related to emotional processing (212), these approaches point into new avenues of post-stroke rehabilitation opening new frames for the recovery potential after stroke.

12. Cramer SC. Repairing the human brain after stroke: I. Mechanisms of spontaneous recovery. Ann Neurol (2008) 63:272-87. doi:10.1002/ ana. 21393

13. Cramer SC. Repairing the human brain after stroke: II. Restorative therapies. Ann Neurol (2008) 63:549-60. doi:10.1002/ana.21412

14. Wittenberg GF, Chen R, Ishii K, Bushara KO, Eckloff S, Croarkin E, et al. Constraint-induced therapy in stroke: magnetic-stimulation motor maps and cerebral activation. Neurorehabil Neural Repair (2003) 17:48-57.

15. Haselbach D, Renggli A, Carda S, Croquelois A. Determinants of neurological functional recovery potential after stroke in young adults. Cerebrovasc Dis Extra (2014) 4:77-83. doi:10.1159/000360218

16. Hossmann KA. Viability thresholds and the penumbra of focal ischemia. Ann Neurol (1994) 36:557-65. doi:10.1002/ana.410360404

17. Heiss WD, Huber M, Fink GR, Herholz K, Pietrzyk U, Wagner R, et al. Progressive derangement of periinfarct viable tissue in ischemic stroke. $J$ Cereb Blood Flow Metab (1992) 12:193-203. doi:10.1038/jcbfm.1992.29

18. Dirnagl U, Iadecola C, Moskowitz MA. Pathobiology of ischaemic stroke: an integrated view. Trends Neurosci (1999) 22:391-7. doi:10.1016/ S0166-2236(99)01401-0

19. Dohmen C, Sakowitz OW, Fabricius M, Bosche B, Reithmeier T, Ernestus RI, et al. Spreading depolarizations occur in human ischemic stroke with high incidence. Ann Neurol (2008) 63:720-8. doi:10.1002/ana.21390

20. Dreier JP, Major S, Manning A, Woitzik J, Drenckhahn C, Steinbrink J, et al. Cortical spreading ischaemia is a novel process involved in ischaemic damage in patients with aneurismal subarachnoid haemorrhage. Brain (2009) 132:1866-81. doi:10.1093/brain/awp102

21. Heiss WD, Sobesky J, Smekal UV, Kracht LW, Lehnhardt FG, Thiel A, et al. Probability of cortical infarction predicted by flumazenil binding and diffusion-weighted imaging signal intensity: a comparative positron emission tomography/magnetic resonance imaging study in early ischemic stroke. Stroke (2004) 35:1892-8. doi:10.1161/01.STR.0000134746.93535.9b

22. Moustafa RP, Baron JC. Pathophysiology of ischaemic stroke: insights from imaging, and implications for therapy and drug discovery. $\mathrm{Br} J$ Pharmacol (2008) 153(Suppl 1):S44-54. doi:10.1038/sj.bjp.0707530

23. Neumann-Haefelin T, Wittsack H-J, Wenserski F, Siebler M, Seitz RJ, Mödder $\mathrm{U}$, et al. Diffusion- and perfusion-weighted MRI. The DWI/PWI mismatch region in acute stroke. Stroke (1999) 30:1591-7. 
24. Rother J, Schellinger PD, Gass A, Siebler M, Villringer A, Fiebach JB, et al. Effect of intravenous thrombolysis on MRI parameters and functional outcome in acute stroke <6 hours. Stroke (2002) 33:2438-45. doi:10.1161/01. STR.0000030109.12281.23

25. Olivot JM, Mlynash M, Thijs VN, Kemp S, Lansberg MG, Wechsler L, et al. Relationships between infarct growth, clinical outcome, and early recanalization in diffusion and perfusion imaging for understanding stroke evolution (DEFUSE).Stroke(2008) 39:2257-63. doi:10.1161/STROKEAHA.107.511535

26. Sobesky J, Zaro Weber O, Lehnhardt FG, Hesselmann V, Thiel A, Dohmen $\mathrm{C}$, et al. Which time-to-peak threshold best identifies penumbral flow? A comparison of perfusion-weighted magnetic resonance imaging and positron emission tomography in acute ischemic stroke. Stroke (2004) 35:2843-7. doi:10.1161/01.STR.0000147043.29399.f6

27. Sobesky J, Zaro Weber O, Lehnhardt FG, Hesselmann V, Neveling M, Jacobs A, et al. Does the mismatch match the penumbra? magnetic resonance imaging and positron emission tomography in early ischemic stroke. Stroke (2005) 36:980-5. doi:10.1161/01.STR.0000160751.79241.a3

28. Beaulieu C, de Crespigny A, Tong DC, Moseley ME, Albers GW, Marks MP. Longitudinal magnetic resonance imaging study of perfusion and diffusion in stroke: evolution of lesion volume and correlation with clinical outcome. Ann Neurol (1999) 46:568-78. doi:10.1002/1531-8249(199910)46:4<568::AID-ANA4>3.0.CO;2-R

29. Røhl L, Ostergaard L, Simonsen CZ, Vestergaard-Poulsen P, Andersen G, Sakoh M, et al. Viability thresholds of ischemic penumbra of hyperacute stroke defined by perfusion-weighted MRI and apparent diffusion coefficient. Stroke (2001) 32:1140-6. doi:10.1161/01.STR.32.5.1140

30. Wittsack HJ, Ritzl A, Fink GR, Wenserski F, Siebler M, Seitz RJ, et al. MR imaging in acute stroke: diffusion-weighted and perfusion imaging parameters for predicting infarct size. Radiology (2002) 222:397-403. doi:10.1148/ radiol.2222001731

31. Lee LJ, Kidwell CS, Alger J, Starkman S, Saver JL. Impact on stroke subtype diagnosis of early diffusion-weighted magnetic resonance imaging and magnetic resonance angiography. Stroke (2000) 31:1081-9. doi:10.1161/01. STR.31.5.1081

32. Li F, Liu KF, Silva MD, Omae T, Sotak CH, Fenstermacher JD, et al. Transient and permanent resolution of ischemic lesions on diffusion-weighted imaging after brief periods of focal ischemia in rats: correlation with histopathology. Stroke (2000) 31:946-54. doi:10.1161/01.STR.31.4.946

33. Saleh A, Schroeter M, Jonkmanns C, Hartung HP, Mödder U, Jander S. In vivo MRI of brain inflammation in human ischaemic stroke. Brain (2004) 127:1670-7. doi:10.1093/brain/awh191

34. Schroeter M, Saleh A, Wiedermann D, Hoehn M, Jander S. Histochemical detection of ultrasmall superparamagnetic iron oxide (USPIO) contrast medium uptake in experimental brain ischemia. Magn Reson Med (2004) 52:403-6. doi:10.1002/mrm.20142

35. Price CJ, Wang D, Menon DK, Guadagno JV, Cleij M, Fryer T, et al. Intrinsic activated microglia map to the peri-infarct zone in the subacute phase of ischemic stroke. Stroke (2006) 37:1749-53. doi:10.1161/01. STR.0000226980.95389.0b

36. Saleh A, Schroeter M, Ringelstein A, Hartung HP, Siebler M, Mödder U, et al. Iron oxide particle-enhanced MRI suggests variability of brain inflammation at early stages after ischemic stroke. Stroke (2007) 38:2733-7. doi:10.1161/ STROKEAHA.107.481788

37. McCombe PA, Read SJ. Immune and inflammatory responses to stroke: good or bad? Int J Stroke (2008) 3:254-65. doi:10.1111/j.1747-4949.2008.00222.x

38. Merino JG, Latour LL, An L, Hsia AW, Kang DW, Warach S. Reperfusion half-life: a novel pharmacodynamic measure of thrombolytic activity. Stroke (2008) 39:2148-50. doi:10.1161/STROKEAHA.107.510818

39. Heiss WD, Grond M, Thiel A, von Stockhausen HM, Rudolf J, Ghaemi M, et al. Tissue at risk of infarction rescued by early reperfusion: a positron emission tomography study in systemic recombinant tissue plasminogen activator thrombolysis of acute stroke. J Cereb Blood Flow Metab (1998) 18:1298-307. doi:10.1097/00004647-199812000-00004

40. Kidwell CS, Saver JL, Starkman S, Duckwiler G, Jahan R, Vespa P, et al. Late secondary ischemic injury in patients receiving intraarterial thrombolysis. Ann Neurol (2002) 52:698-703. doi:10.1002/ana.10380

41. Seitz RJ, Meisel S, Weller P, Junghans U, Wittsack H-J, Siebler M. The initial ischemic event: PWI and ADC for stroke evolution. Radiology (2005) 237:1020-8. doi:10.1148/radiol.2373041435
42. Ogata T, Nagakane Y, Christensen S, Ma H, Campbell BC, Churilov L, et al. A topographic study of the evolution of the MR DWI/PWI mismatch pattern and its clinical impact: a study by the EPITHET and DEFUSE investigators. Stroke (2011) 42:1596-601. doi:10.1161/STROKEAHA.110.609016

43. Alexandrov AV, Demchuk AM, Felberg RA, Christou I, Barber PA, Burgin WS, et al. High rate of complete recanalization and dramatic clinical recovery during tPA infusion when continuously monitored with $2-\mathrm{MHz}$ transcranial doppler monitoring. Stroke (2000) 31:610-4. doi:10.1161/01.STR.31.3.610

44. Alexandrov AV, Burgin WS, Demchuk AM, El Mitwalli A, Grotta JC. Speed of intracranial clot lysis with intravenous tissue plasminogen activator therapy: sonographic classification and short-term improvement. Circulation (2001) 103:2897-902. doi:10.1161/01.CIR.103.24.2897

45. Parsons MW, Barber PA, Desmond PM, Baird TA, Darby DG, Byrnes G, et al. Acute hyperglycemia adversely affects stroke outcome: a magnetic resonance imaging and spectroscopy study. Ann Neurol (2002) 52:20-8. doi:10.1002/ ana. 10241

46. Hillis AE, Gold L, Kannan V, Cloutman L, Kleinman JT, Newhart M, et al. Site of the ischemic penumbra as a predictor of potential for recovery of functions. Neurology (2008) 71:184-9. doi:10.1212/01.wnl.0000317091.17339.98

47. Almekhlafi MA, Hu WY, Hill MD, Auer RN. Calcification and endothelialisation of thrombi in acute stroke. Ann Neurol (2008) 64:344-52. doi:10.1002/ ana. 21404

48. Arac A, Blanchard V, Lee M, Steinberg GK. Assessment of outcome following decompressive craniectomy for malignant middle cerebral artery infarction in patients older than 60 years of age. Neurosurg Focus (2009) 26(6):E3. doi: 10.3171/2009.3.FOCUS0958

49. Thrift AG, Dewey HM, MacDonnell RA, McNeil JJ, Donnan GA. Incidence of the major stroke subtypes: initial findings from the North East Melbourne Stroke Incidence Study (NEMESIS). Stroke (2001) 32:1732-8. doi:10.1161/01. STR.32.8.1732

50. Dewey HM, Sturm J, Donnan GA, MacDonnel RA, McNeill JJ, Thrift AG. Incidence and outcome of subtypes of ischaemic stroke: initial results from the North East Melbourne Stroke Incidence Study (NEMESIS). Cerebrovasc Dis (2003) 15:133-9. doi:10.1159/000067142

51. Finelli PF. Neuroimaging in acute posterior cerebral artery infarction. Neurologist (2008) 14:170-80. doi:10.1097/NRL.0b013e3181627679

52. Kang SY, Kim JS. Anterior cerebral artery infarction. Stroke mechanism and clinical-imaging study in 100 patients. Neurology (2008) 70:2386-93. doi:10.1212/01.wnl.0000314686.94007.d0

53. Bang OY, Saver JL, Buck BH, Alger JR, Starkman S, Ovbiagele B, et al. Impact of collateral flow on tissue fate in acute ischaemic stroke. J Neurol Neurosurg Psychiatry (2008) 79:625-9. doi:10.1136/jnnp.2007.132100

54. Liebeskind DS, Cotsonis GA, Saver JL, Lynn MJ, Turan TN, Cloft HJ, et al. Collaterals dramatically alter stroke risk in intracranial atherosclerosis. Ann Neurol (2011) 69:963-74. doi:10.1002/ana.22354

55. Binkofski F, Seitz RJ, Arnold S, Claßen J, Benecke R, Freund H-J. Thalamic metabolism and integrity of the pyramidal tract determine motor recovery in stroke. Ann Neurol (1996) 39:460-70. doi:10.1002/ana.410390408

56. Kim JS. Predominant involvement of a particular group of fingers due to small, cortical infarction. Neurology (2001) 56:1677-82. doi:10.1212/ WNL.56.12.1677

57. Binkofski F, Seitz RJ. Modulation of the BOLD-response in early recovery from sensorimotor stroke. Neurology (2004) 63:1223-9. doi:10.1212/01. WNL.0000140468.92212.BE

58. Schäfer R, Popp K, Jörgens S, Lindenberg R, Franz M, Seitz RJ. Alexithymialike disorder in right anterior cingulate infarction. Neurocase (2007) 13:201-8. doi:10.1080/13554790701494964

59. Barton JJ. Structure and function in acquired prosopagnosia: lessons from a series of 10 patients with brain damage. J Neuropsychol (2008) 2:197-225. doi :10.1348/174866407X214172

60. Hömke L, Amunts K, Bönig L, Fretz C, Binkofski F, Zilles K, et al. Analysis of lesions in patients with unilateral tactile agnosia using cytoarchitectonic probabilistic maps. Hum Brain Mapp (2009) 30:1444-56. doi:10.1002/hbm.20617

61. Burke Quinlan E, Dodakian L, See J, McKenzie A, Le V, Wojnowicz M, et al. Neural function, injury, and stroke subtype predict treatment gains after stroke. Ann Neurol (2015) 77:132-45. doi:10.1002/ana.24309

62. Karnath HO, Rorden C, Ticini LF. Damage to white matter fibre tracts in acute spatial neglect. Cereb Cortex (2009) 19:2331-7. doi:10.1093/cercor/ bhn 250 
63. Pazzaglia M, Smania N, Corato E, Aglioti SM. Neural underpinnings of gesture discrimination in patients with limb apraxia. J Neurosci (2008) 28:3030-41. doi:10.1523/JNEUROSCI.5748-07.2008

64. Rusconi E, Pinel P, Eger E, LeBihan D, Thirion B, Dehaene S, et al. A disconnection account of Gerstmann syndrome: functional neuroanatomy evidence. Ann Neurol (2009) 66:654-62. doi:10.1002/ana.21776

65. Hamzei F, Dettmers C, Rijntjes M, Weiller C. The effect of cortico-spinal tract damage on primary sensorimotor cortex activation after rehabilitation therapy. Exp Brain Res (2008) 190:329-36. doi:10.1007/ s00221-008-1474-x

66. Kim YH, Kim DS, Hong JH, Park CH, Hua N, Bickart KC, et al. Corticospinal tract location in internal capsule of human brain: diffusion tensor tractography and functional MRI study. Neuroreport (2008) 28:817-20. doi:10.1097/ WNR.0b013e328300a086

67. Schiemanck SK, Kwakkel G, Post MW, Kappelle LJ, Prevo AJ. Impact of internal capsule lesions on outcome of motor hand function at one year post-stroke. J Rehabil Med (2008) 40:96-101. doi:10.2340/16501977-0130

68. Schaechter JD, Fricker ZP, Perdue KL, Helmer KG, Vangel MG, Greve DN, et al. Microstructural status of ipsilesional and contralesional corticospinal tract correlates with motor skill in chronic stroke patients. Hum Brain Mapp (2009) 30:3461-74. doi:10.1002/hbm.20770

69. Vitali P, Abutalebi J, Tettamanti M, Danna M, Ansaldo AI, Perani D, et al. Training-induced brain remapping in chronic aphasia: a pilot study. NeurorehabilNeuralRepair(2007)21:152-60.doi:10.1177/1545968306294735

70. Connell LA, Lincoln NB, Radford KA. Somatosensory impairment after stroke: frequency of different deficits and their recovery. Clin Rehabil (2008) 22:758-67. doi:10.1177/0269215508090674

71. Poggel DA, Mueller I, Kasten E, Sabel BA. Multifactorial predictors and outcome variables of vision restoration training in patients with post-geniculate visual field loss. Restor Neurol Neurosci (2008) 26:321-39.

72. Brodtmann A, Puce A, Darby D, Donnan G. Serial functional imaging poststroke reveals visual cortex reorganization. Neurorehabil Neural Repair (2009) 23:150-9. doi:10.1177/1545968308321774

73. von Kummer R, Meyding-Lamadé U, Forsting M, Rosin L, Rieke K, Hacke W, et al. Sensitivity and prognostic value of early CT in occlusion of the middle cerebral artery trunk. AJNR Am J Neuroradiol (1994) 15:9-15.

74. Delgado-Mederos R, Rovira A, Alvarez-Sabín J, Ribó M, Munuera J, Rubiera M, et al. Speed of tPA-induced clot lysis predicts DWI lesion evolution in acute stroke. Stroke (2007) 38:955-60. doi:10.1161/01. STR.0000257977.32525.6e

75. Seitz RJ, Donnan GA. Role of neuroimaging in promoting long-term recovery from ischemic stroke. J Magn Reson Imaging (2010) 32:756-72. doi:10.1002/ jmri.22315

76. Paolucci S, Antonucci G, Grasso MG, Bragoni M, Coiro P, De Angelis D, et al. Functional outcome of ischemic and hemorrhagic stroke patients after inpatient rehabilitation. A matched comparison. Stroke (2003) 34:2861-5. doi:10.1161/01.STR.0000102902.39759.D3

77. Bang OY, Lee PH, Heo KG, Joo US, Yoon SR, Kim SY. Stroke specific DWI lesion patterns predict prognosis after acute ischaemic stroke within the MCA territory. J Neurol Neurosurg Psychiatry (2005) 76:1222-8. doi:10.1136/ jnnp.2004.059998

78. Wang X, Lam WW, Fan YH, Graham CA, Rainer TH, Wong KS. Topographic patterns of small subcortical infarcts associated with MCA stenosis: a diffusion-weighted MRI study. J Neuroimaging (2006) 16:266-71. doi:10.1111/j.1552-6569.2006.00027.x

79. Crafton KR, Mark AN, Cramer SC. Improved understanding of cortical injury by incorporating measures of functional anatomy. Brain (2003) 126:1650-9. doi:10.1093/brain/awg159

80. Rey B, Frischknecht R, Maeder P, Clarke S. Patterns of recovery following focal hemispheric lesions: relationship between lasting deficit and damage to specialized networks. Restor Neurol Neurosci (2007) 25:285-94.

81. Donnan GA, Bladin PF, Berkovic SF, Longley WA, Saling MM. The stoke syndrome of striatocapsular infarction. Brain (1991) 114:51-70.

82. Seitz RJ, Sondermann V, Wittsack H-J, Siebler M. Lesion patterns in successful and failed thrombolysis in middle cerebral artery stroke. Neuroradiology (2009) 51:865-71. doi:10.1007/s00234-009-0576-x

83. Stoeckel MC, Meisel S, Wittsack HJ, Seitz RJ. Pattern of cortex and white matter involvement in severe middle cerebral artery ischemia. J Neuroimaging (2007) 17:131-40. doi:10.1111/j.1552-6569.2007.00102.x
84. Saur D, Lange R, Baumgaertner A, Schraknepper V, Willmes K, Rijntjes $\mathrm{M}$, et al. Dynamics of language reorganization after stroke. Brain (2006) 129:1371-84. doi:10.1093/brain/aw1090

85. Fisher CM. Lacunar strokes and infarcts: a review. Neurology (1982) 32:871-6. doi:10.1212/WNL.32.8.871

86. Boiten J, Lodder J. Lacunar infarcts. Pathogenesis and validity of the clinical syndromes. Stroke (1991) 22:1374-8. doi:10.1161/01.STR.22.11.1374

87. Stinear CM, Barber PA, Smale PR, Coxon JP, Fleming MK, Byblow WD. Functional potential in chronic stroke patients depends on corticospinal tract integrity. Brain (2007) 130:170-80. doi:10.1093/brain/awl333

88. Lindenberg R, Zhu LL, Rüber T, Schlaug G. Predicting functional motor potential in chronic stroke patients using diffusion tensor imaging. Hum Brain Mapp (2012) 33:1040-51. doi:10.1002/hbm.21266

89. Kretschmann HJ. Localisation of the corticospinal fibres in the internal capsule in man. J Anat (1988) 160:219-25.

90. Wenzelburger R, Kopper F, Frenzel A, Stolze H, Klebe S, Brossmann A, et al. Hand coordination following capsular stroke. Brain (2005) 128:64-74. doi:10.1093/brain/awh317

91. Fornage M, Debette S, Bis JC, Schmidt H, Ikram MA, Dufouil C, et al. Genome-wide association studies of cerebral white matter lesion burden: the CHARGE consortium. Ann Neurol (2011) 69:928-39. doi:10.1002/ana.22403

92. Surikova I, Meisel S, Siebler M, Wittsack H-J, Seitz RJ. Significance of the perfusion-diffusion mismatch area in chronic cerebral ischemia. J Magn Reson Imaging (2006) 24:771-8. doi:10.1002/jmri.20686

93. Blondin D, Seitz RJ, Rusch O, Janssen H, Andersen K, Wittsack HJ, et al. Clinical impact of MRI perfusion disturbances and normal diffusion in acute stroke patients. Eur J Radiol (2009) 71:1-10. doi:10.1016/j.ejrad.2008.04.003

94. Kurada S, Houkin K. Moyamoya disease: current concepts and future perspectives. Lancet Neurol (2008) 7:1056-66. doi:10.1016/S1474-4422(08)70240-0

95. Lee J-I, Jander S, Oberhuber A, Schelzig H, Hänggi D, Turowski B, et al. Stroke in patients with occlusion of the internal carotid artery: options for treatment. Expert Rev Neurother (2014) 14(10):1153-67. doi:10.1586/14737 175.2014.955477

96. Taoufik E, Probert L. Ischemic neuronal damage. Curr Pharm Des (2008) 14:3565-73. doi:10.2174/138161208786848748

97. Witte OW, Bidmon H-J, Schiene K, Redecker C, Hagemann G. Functional differentiation of multiple perilesional zones after focal cerebral ischemia. J Cereb Blood Flow Metab (2000) 20:1149-65. doi:10.1097/00004647-200008000-00001

98. Redecker C, Luhmann HJ, Hagemann G, Fritschy JM, Witte OW. Differential downregulation of GABAA receptor subunits in widespread brain regions in the freeze-lesion model of focal cortical malformations. J Neurosci (2000) 20:5045-53.

99. Carmichael ST, Wei L, Rovainen CM, Woolsey TA. Growth-associated gene expression after stroke: evidence for a growth-promoting region in the peri-infarct cortex. Exp Neurol (2005) 193:291-311. doi:10.1016/j. expneurol.2005.01.004

100. Centonze D, Rossi S, Tortiglione A, Picconi B, Prosperetti C, De Chiara $\mathrm{V}$, et al. Synaptic plasticity during recovery from permanent occlusion of the middle cerebral artery. Neurobiol Dis (2007) 27:44-53. doi:10.1016/j. nbd.2007.03.012

101. Guadagno JV, Jones PS, Aigbirhio FI, Wang D, Fryer TD, Day DJ, et al. Selective neuronal loss in rescued penumbra relates to initial hypoperfusion. Brain (2008) 131:2666-78. doi:10.1093/brain/awn175

102. Frost SB, Barbay S, Friel KM, Plautz EJ, Nudo RJ. Reorganization of remote cortical regions after ischemic brain injury: a potential substrate for stroke recovery. J Neurophysiol (2003) 89:3205-14. doi:10.1152/jn.01143.2002

103. Dancause N, Barbay S, Frost SB, Plautz EJ, Chen D, Zoubina EV, et al. Extensive cortical rewiring after brain injury. J Neurosci (2005) 25:10167-79. doi:10.1523/JNEUROSCI.3256-05.2005

104. Nudo R, Wise B, SiFuentes F, Milliken G. Neural substrates for the effects of rehabilitative training on motor recovery after ischemic infarct. Science (1996) 272:1791-4. doi:10.1126/science.272.5269.1791

105. Biernaskie J, Corbett D. Enriched rehabilitative training promotes improved forelimb motor function and enhanced dendritic growth after focal ischemic injury. J Neurosci (2001) 21:5272-80.

106. Liew SL, Santarnecchi E, Buch ER, Cohen LG. Non-invasive brain stimulation in neurorehabilitation: local and distant effects for motor recovery. Front Hum Neurosci (2014) 27(8):378. doi:10.3389/fnhum.2014.00378 
107. Cincenelli P, Pascualetti P, Zaccagnini M, Traversa R, Oliveri M, Rossini PM. Interhemispheric asymmetries of motor cortex excitability in the postacute stroke stage: a paired-pulse transcranial magnetic stimulation study. Stroke (2003) 34:2653-8. doi:10.1161/01.STR.0000092122.96722.72

108. Bütefisch CM, Wessling M, Netz J, Seitz RJ, Hömberg V. Excitability and of ipsiand contralesional motor cortices and their relationship in stroke patients. Neurorehabil Neural Repair (2008) 22:4-21. doi:10.1177/1545968307301769

109. Manganotti P, Acler M, Zanette GP, Smania N, Fiaschi A. Motor cortical disinhibition during early and late recovery after stroke. Neurorehabil Neural Repair (2008) 22:396-403. doi:10.1177/1545968307313505

110. Liepert J, Haevernick K, Weiller C, Barzel A. The surround inhibition determines therapy-induced cortical reorganization. Neuroimage (2006) 32:1216-20. doi:10.1016/j.neuroimage.2006.05.028

111. Hamzei F, Knab R, Weiller C, Röther J. The influence of extra- and intracranial artery disease on the BOLD signal in fMRI. Neuroimage (2003) 20:1393-9. doi:10.1016/S1053-8119(03)00384-7

112. Jaillard A, Martin CD, Garambois K, Lebas JF, Hommel M. Vicarious function within the human primary motor cortex? A longitudinal fMRI stroke study. Brain (2005) 128:1122-38. doi:10.1093/brain/awh456

113. Boake C, Noser EA, Ro T, Baraniuk S, Gaber M, Johnson R, et al. Constraintinduced movement therapy during early stroke rehabilitation. Neurorehabil Neural Repair (2008) 21:14-24. doi:10.1177/1545968306291858

114. Bütefisch CM, Netz J, Wessling M, Seitz RJ, Hömberg V. Remote changes in cortical excitability after stroke. Brain (2003) 126:470-81. doi:10.1093/brain/ awg044

115. Marshall RS, Zarahn E, Alon L, Minzer B, Lazar RM, Krakauer JW. Early imaging correlates of subsequent motor recovery after stroke. Ann Neurol (2009) 65:596-602. doi:10.1002/ana.21636

116. Marshall RS, Perera GM, Lazar RM, Krakauer JW, Constantine RC, DeLaPaz RL. Evolution of cortical activation during recovery from corticospinal tract infarction. Stroke (2000) 31:656-61. doi:10.1161/01.STR.31.3.656

117. Nhan H, Barquist K, Bell K, Esselman P, Odderson I, Cramer S. Brain function early after stroke in relation to subsequent recovery. J Cereb Blood Flow Metab (2004) 24:756-63. doi:10.1097/01.WCB.0000122744.72175.9C

118. Askam T, Indredavik B, Vangberg T, Haberg A. Motor network changes associated with successful motor skill relearning after acute ischemic stroke: a longitudinal functional magnetic resonance imaging study. Neurorehabil Neural Repair (2009) 23:295-304. doi:10.1177/1545968308322840

119. Liew SL, Santarnecchi E, Buch ER, Cohen LG. Non-invasive brain stimulation in neurorehabilitation: local and distant effects for motor recovery. Front Hum Neurosci (2014) 8:378. doi:10.3389/fnhum.2014.00378

120. Reis J, Schambra HM, Cohen LG, Buch ER, Fritsch B, Zarahn E, et al. Noninvasive cortical stimulation enhances motor skill acquisition over multiple days through an effect on consolidation. Proc Natl Acad Sci U S A (2009) 106:1590-5. doi:10.1073/pnas.0805413106

121. Nowak DA, Grefkes C, Dafotakis M, Eickhoff S, Küst J, Karbe H, et al. Effects of low-frequency repetitive transcranial magnetic stimulation of the contralesional primary motor cortex on movement kinematics and neural activity in subcortical stroke. Arch Neurol (2008) 65:741-7. doi:10.1001/archneur.65.6.741

122. Bhatt E, Nagpal A, Greer KH, Grunewald TK, Steele JL, Wiemiller JW, et al. Effect of finger tracking combined with electrical stimulation on brain reorganization and hand function in subjects with stroke. Exp Brain Res (2007) 182:435-47. doi:10.1007/s00221-007-1001-5

123. Winhuisen L, Thiel A, Schumacher B, Kessler J, Rudolf J, Haupt WF, et al. The right inferior frontal gyrus and poststroke aphasia: a follow-up investigation. Stroke (2007) 38:1286-92. doi:10.1161/01.STR.0000259632.04324.6c

124. Marangolo P, Rizzi C, Peran P, Piras F, Sabatini U. Parallel recovery in a bilingual aphasic: a neurolinguistic and fMRI study. Neuropsychology (2009) 23:405-9. doi:10.1037/a0014824

125. Muehlbacher W, Richards C, Ziemann U, Hallett M. Improving hand function in chronic stroke. Arch Neurol (2002) 59:1278-82. doi:10.1001/ archneur.59.8.1278

126. Floel A, Nagorsen U, Werhahn KJ, Ravindran S, Birbaumer N, Knecht S, et al. Influence of somatosensory input on motor function in patients with chronic stroke. Ann Neurol (2004) 56:206-12. doi:10.1002/ana.20170

127. Fregni F, Boggio PS, Mansur CG, Wagner T, Ferreira MJ, Lima MC, et al. Transcranial direct current stimulation of the unaffected hemisphere in stroke patients. Neuroreport (2005) 16:1551-5. doi:10.1097/01. wnr.0000177010.44602.5e
128. Hummel F, Celnik P, Giraux P, Floel A, Wu WH, Gerloff C, et al. Effects of non-invasive cortical stimulation on skilled motor function in chronic stroke. Brain (2005) 128:490-9. doi:10.1093/brain/awh369

129. Lindenberg R, Renga V, Zhu LL, Nair D, Schlaug G. Bihemispheric brain stimulation facilitates motor recovery in chronic stroke patients. Neurology (2010) 75:2176-84. doi:10.1212/WNL.0b013e318202013a

130. Nair DG, Hutchinson S, Fregni F, Alexander M, Pascual-Leone A, Schlaug G. Imaging correlates of motor recovery from cerebral infarction and their physiological significance in well-recovered patients. Neuroimage (2007) 34:253-63. doi:10.1016/j.neuroimage.2006.09.010

131. Talelli P, Greenwood RJ, Rothwell JC. Exploring theta burst stimulation as an intervention to improve motor recovery in chronic stroke. Clin Neurophysiol (2007) 118:333-42. doi:10.1016/j.clinph.2006.10.014

132. Khedr EM, Abdel-Fadeil MR, Farghali A, Qaid M. Role of 1 and 3 $\mathrm{Hz}$ repetitive transcranial magnetic stimulation on motor function recovery after acute ischaemic stroke. Eur J Neurol (2009) 16:1323-30. doi:10.1111/j.1468-1331.2009.02746.x

133. Celnik P, Paik NJ, Vandermeeren Y, Dimyan M, Cohen LG. Effects of combined peripheral nerve stimulation and brain polarization on performance of a motor sequence task after chronic stroke. Stroke (2009) 40:1764-71. doi:10.1161/STROKEAHA.108.540500

134. Fries W, Danek A, Witt TN. Motor responses after transcranial electrical stimulation of cerebral hemispheres with a degenerated pyramidal tract. Ann Neurol (1991) 29:646-50. doi:10.1002/ana.410290612

135. SchaechterJD, Perdue KL, Wang R. Structural damage to the corticospinal tract correlates with bilateral sensorimotor cortex reorganization in stroke patients. Neuroimage (2008) 39:1370-82. doi:10.1016/j.neuroimage.2007.09.071

136. Lindenberg R, Renga V, Zhu LL, Betzler F, Alsop D, Schlaug G. Structural integrity of corticospinal motor fibres predict motor impairment in chronic stroke. Neurology (2010) 74:280-7. doi:10.1212/WNL.0b013e3181ccc6d9

137. Canedo A. Primary motor cortex influences on the descending and ascending systems. Prog Neurobiol (1997) 51:287-335. doi:10.1016/ S0301-0082(96)00058-5

138. Lang CE, Schieber MH. Reduced muscle selectivity during individuated finger movements in humans after damage to the motor cortex or corticospinal tract. J Neurophysiol (2004) 91:1722-33. doi:10.1152/jn.00805.2003

139. Kennedy RR. Corticospinal, rubrospinal and rubro-olivary projections: a unifying hypothesis. Trends Neurosci (1990) 13:474-9. doi:10.1016/0166-2236(90)90079-P

140. Carey LM, Abbott DF, Harvey MR, Puce A, Seitz RJ, Donnan GA. Relationship between touch impairment and brain activation after lesions of subcortical and cortical somatosensory regions. Neurorehabil Neural Repair (2011) 25:443-57. doi:10.1177/1545968310395777

141. Liepert J, Storch P, Fritsch A, Weiller C. Motor cortex disinhibition in acute stroke. Clin Neurophysiol (2000) 111:671-6. doi:10.1016/ S1388-2457(99)00312-0

142. Hummel FC, Steven B, Hoppe J, Heise K, Thomalla G, Cohen LG, et al. Deficient intracortical inhibition (SICI) during movement preparation after chronic stroke. Neurology (2009) 19:1766-72. doi:10.1212/WNL.0b013e3181a609c5

143. Lewis GN, Perreault EJ. Side of lesion influences bilateral activation in chronic, post-stroke hemiparesis. Clin Neurophysiol (2007) 118:2050-62. doi:10.1016/j.clinph.2007.08.027

144. Misawa S, Kuwabara S, Matsuda S, Honma K, Ono J, Hattori T. The ipsilateral cortico-spinal tract is activated after hemiparetic stroke. Eur J Neurol (2008) 15:706-11. doi:10.1111/j.1468-1331.2008.02168.x

145. Schwerin S, Dewald JPA, Haztl M, Jovanovich S, Nickeas M, MacKinnon C. Ipsilateral versus contralateral cortical motor projections to a shoulder adductor in chronic hemiparetic stroke: implications for the expression of arm synergies. Exp Brain Res (2008) 185:509-19. doi:10.1007/s00221-007-1169-8

146. Pannek K, Chalk JB, Finnigan S, Rose SE. Dynamic corticospinal white matter connectivity changes during stroke recovery: a diffusion tensor probabilistic tractography study. J Magn Reson Imaging (2009) 29:529-36. doi:10.1002/jmri.21627

147. Lang CE, Dejong SL, Beebe JA. Recovery of thumb and finger extension and its relation to grasp performance after stroke. J Neurophysiol (2009) 102:451-9. doi:10.1152/jn.91310.2008

148. Foltys H, Krings T, Meister IG, Sparing R, Boroojerdi B, Thron A, et al. Motor representation in patients rapidly recovering after stroke: a functional magnetic resonance imaging and transcranial magnetic stimulation study. Clin Neurophysiol (2003) 114:2404-2015. doi:10.1016/S1388-2457(03)00263-3 
149. Bütefisch CM, Kleiser R, Körber B, Müller K, Wittsack HJ, Hömberg V, et al. Recruitment of contralesional motor cortex in stroke patients with recovery of hand function. Neurology (2005) 64:1067-9. doi:10.1212/01. WNL.0000154603.48446.36

150. Nelles G, Cramer S, Schaechter J, Kaplan J, Finklestein S. Quantitative assessment of mirror movements after stroke. Stroke (1998) 29:1182-7. doi:10.1161/01.STR.29.6.1182

151. Seitz RJ, Knorr U, Azari NP, Herzog H, Freund H-J. Recruitment of a visuomotor network in stroke recovery. Restor Neurol Neurosci (1999) 14:25-33.

152. Grefkes C, Nowak DA, Eickhoff SB, Dafotakis M, Küst J, Karbe H, et al. Cortical connectivity after subcortical stroke assessed with functional magnetic resonance imaging. Ann Neurol (2008) 63:236-46. doi:10.1002/ana.21228

153. Kimberley TJ, Lewis SM, Strand C, Rice BD, Hall S, Slivnik P. Neural substrates of cognitive load changes during a motor task in subjects with stroke. J Neurol Phys Ther (2008) 32:110-7. doi:10.1097/NPT.0b013e318183d716

154. Sharma N, Baron JC, Rowe JB. Motor imagery after stroke: relating outcome to motor network connectivity. Ann Neurol (2009) 66:604-16. doi:10.1002/ ana. 21810

155. Ebrahim S, Nouri F, Barer D. Cognitive impairment after stroke. Age Ageing (1985) 14:345-8. doi:10.1093/ageing/14.6.345

156. Robinson RG, Starr LB, Lipsey JR, Rao K, Price TR. A two-year longitudinal study of poststroke mood disorders. In-hospital prognostic factors associated with six-month outcome. J Nerv Ment Dis (1985) 173:221-6. doi:10.1097/00005053-198504000-00003

157. Karlinski M, Kobayashi A, Czlonkowska A, Mikulik R, Vaclavik D, Brozman $\mathrm{M}$, et al. Role of preexisting disability in patients treated with intravenous thrombolysis for ischemic stroke. Stroke (2014) 45:770-5. doi:10.1161/ STROKEAHA.113.003744

158. Seitz RJ, Sukiennik J, Siebler M. Outcome after systemic thrombolysis is predicted by age and stroke severity - an open label experience with rtPA and tirofiban. Neurol Int (2012) 4:e9,35-39. doi:10.4081/ni.2012.e9

159. Aron AW, Staff I, Fortunato G, McCullough LD. Prestroke living situation and depression contribute to initial stroke severity and stroke recovery. J Stroke Cerebrovasc Dis (2015) 24(2):492-9. doi:10.1016/j. jstrokecerebrovasdis.2014.09.024

160. Guidetti D, Rota E, Morelli N, Immovilli P. Migraine and stroke: "vascular" comorbidity. Front Neurol (2014) 5:193. doi:10.3389/fneur.2014.00193

161. Sacco S, Ornello R, Ripa P, Pistoia F, Carolei A. Migraine and hemorrhagic stroke. A meta-analysis. Stroke (2013) 44:3032-8. doi:10.1161/ STROKEAHA.113.002465

162. Brookes RL, Herbert V, Andrew J, Lawrence AJ, Morris RG, Markus HS. Depression in small-vessel disease relates to white matter ultrastructural damage, not disability. Neurology (2014) 83:1417-23. doi:10.1212/ WNL.0000000000000882

163. Pendlebury ST, Rothwell PM. Risk of recurrent stroke, other vascular events and dementia after transient ischaemic attack and stroke. Cerebrovasc Dis (2009) 27(Suppl 3):1-11. doi:10.1159/000209260

164. Oksala NK, Jokinen H, Melkas S, Oksala A, Pohjasvaara T, Hietanen M, et al. Cognitive impairment predicts poststroke death in long-term follow-up. $J$ Neurol Neurosurg Psychiatry (2009) 80:1230-5. doi:10.1136/jnnp.2009.174573

165. Patel M, Coutinho C, Emsley HCA. Prevalence of radiological and clinical cerebrovascular disease in idiopathic Parkinson's disease. Clin Neurol Neurosurg (2011) 113:830-4. doi:10.1016/j.clineuro.2011.05.014

166. de Laat KF, van Norden AG, Gons RA, van Uden IW, Zwiers MP, Bloem BR, et al. Cerebral white matter lesions and lacunar infarcts contribute to the presence of mild Parkinsonian signs. Stroke (2012) 43:2574-9. doi:10.1161/ STROKEAHA.112.657130

167. Huang Y-P, Chen L-S, Ming-Fang Yen M-F, Fann C-Y, Chiu Y-H, Chen H-H, et al. Parkinson's disease is related to an increased risk of ischemic stroke - a population-based propensity score-matched follow-up study. PLoS One (2013) 8:e68314. doi:10.1371/journal.pone.0068314

168. Buchman AS, Leurgans SE, Nag S, Bennett DA, Schneider JA. Cerebrovascular disease pathology and Parkinsonian signs in old age. Stroke (2011) 42:3183-9. doi:10.1161/STROKEAHA.111.623462

169. Chang C-S, Liao C-H, Lin C-C, Lane H-Y, Sung F-C, Kao C-H. Patients with epilepsy are at an increased risk of subsequent stroke: a population-based cohort study. Seizure (2014) 23:377-81. doi:10.1016/j.seizure.2014.02.007

170. Broomfield NM, Terence J, Quinn TJ, Abdul-Rahim AH, Walters MR, Evans JJ. Depression and anxiety symptoms post-stroke/TIA: prevalence and associations in cross-sectional data from a regional stroke registry. $B M C$ Neurol (2014) 2014(14):198. doi:10.1186/s12883-014-0198-8

171. Hornsten C, Lövheim H, Gustafson Y. The association between stroke, depression, and 5-year mortality among very old people. Stroke (2013) 44:2587-9. doi:10.1161/STROKEAHA.113.002202

172. Wu H-C, Chou FH-C, Tsai K-Y, Su C-Y, Shen S-P, Chung T-C. The incidence and relative risk of stroke among patients with bipolar disorder: a seven-year follow-up study. PLoS One (2013) 8:e73037. doi:10.1371/journal. pone. 0073037

173. Seitz RJ, Hildebold T, Simeria K. Spontaneous arm movement activity assessed with accelerometry is a marker for early recovery after stroke. J Neurol (2011) 258:457-63. doi:10.1007/s00415-010-5778-y

174. Ruan J, Seitz RJ. Impaired sleep and reduced spontaneous movement activity in acute stroke: an exploratory study. J Neuro Clsci (2014) 1:8.

175. Bassetti CL, Aldrich MS. Sleep electroencephalogram changes in acute hemispheric stroke. Sleep Med (2001) 2:185-94. doi:10.1016/ S1389-9457(00)00071-X

176. Luu P, TuckerDM,Englander R,Lockfeld A,LutsepH, Oken B. Localizing acute stroke-related EEG changes: assessing the effects of spatial undersampling. $J$ ClinNeurophysiol(2001) 18:302-17.doi:10.1097/00004691-200107000-00002

177. Vock J, Achermann P, Bischof M, Milanova M, Müller C, Nirkko A, et al. Evolution of sleep and sleep EEG after hemispheric stroke. J Sleep Res (2002) 11:331-8. doi:10.1046/j.1365-2869.2002.00316.x

178. Cyril C, Urbain MT, Calvet P, Martinez VL. The clinical significance of periodic lateralized epileptiform discharges in acute ischemic stroke. J Stroke Cerebrovasc Dis (2000) 9:298-302. doi:10.1053/jscd.2000.18734

179. Hensel S, Rockstroh B, Berg P, Elbert T, Schönle PW. Left-hemispheric abnormal EEG activity in relation to impairment and recovery in aphasic patients. Psychophysiology (2004) 41:394-400. doi:10.1111/j.1469-8986.2004.00164x

180. Burghaus L, Hilker R, Dohmen C, Bosche B, Winhuisen L, Galldiks N, et al. Early electroencephalography in acute ischemic stroke: prediction of a malignant course? Clin Neurol Neurosurg (2007) 109:45-9. doi:10.1016/j. clineuro.2006.06.003

181. Airboix A, Comes E, García-Eroles L, Massons JB, Oliveres M, Balcells M. Prognostic value of very early seizures for in-hospital mortality in atherothrombotic infarction. Eur Neurol (2003) 50:78-84. doi:10.1159/000072503

182. Reith J, Jørgensen HS, Nakayama H, Raaschou HO, Olsen TS. Seizures in acute stroke: predictors and prognostic significance. The Copenhagen Stroke Study. Stroke (1997) 28:1585-9. doi:10.1161/01.STR.28.8.1585

183. Jordan KG. Emergency EEG and continuous EEG monitoring in acute ischemic stroke. J Clin Neurophysiol (2004) 21:341-52.

184. Binkofski F, Seitz RJ, Hackländer T, Pawelec D, Mau J, Freund H-J. The recovery of motor functions following hemiparetic stroke: a clinical and MR-morphometric study. Cerebrovasc Dis (2001) 11:273-81. doi:10.1159/000047650

185. Meinzer M, Ebert T, Wienbruch C, Djundja D, Barthel B, Rockstroh B. Intensive language training enhances brain plasticity in chronic aphasia. BMC Biol (2004) 2:20. doi:10.1186/1741-7007-2-20

186. Cheung VH, Gray L, Karunanithi M. Review of accelerometry for determining daily activity among elderly patients. Arch Phys Med Rehabil (2011) 92:998-1014. doi:10.1016/j.apmr.2010.12.040

187. Duncan PW, Lai SM, Keighley J. Defining post-stroke recovery: implications for design and interpretation of drug trials. Neuropharmacology (2000) 39:835-41. doi:10.1016/S0028-3908(00)00003-4

188. Kwakkel G, Kollen BJ, van der Grond J, Prevo AJ. Probability of regaining dexterity in the flaccid upper limb: impact of severity of paresis and time since onset in acute stroke. Stroke (2003) 34:2181-6. doi:10.1161/01. STR.0000087172.16305.CD

189. Beebe JA, Lang CE. Active range of motion predicts upper extremity function 3 months after stroke. Stroke (2009) 40:1772-92. doi:10.1161/ STROKEAHA.108.536763

190. Krebs HI, Volpe B, Hogan N. A working model of stroke recovery from rehabilition robotics practitioners. J Neuroeng Rehabil (2009) 2009(25):6. doi:10.1186/1743-0003-6-6

191. Sprigg N, Gray LJ, Bath PM, Lindenstrøm E, Boysen G, De Deyn PP, et al. Early recovery and functional outcome are related with causal stroke subtype: data from the tinzaparin in acute ischemic stroke trial. J Stroke Cerebrovasc Dis (2004) 16:180-4. doi:10.1016/j.jstrokecerebrovasdis.2007.02.003 
192. Schepers P, Ketelaar M, Visser-Meily AJ, de Groot V, Twisk JW, Lindeman E. Functional recovery differs between ischaemic and haemorrhagic stroke patients. J Rehabil Med (2008) 40:487-9. doi:10.2340/16501977-0198

193. Welmer AK, Holmqvist LW, Sommerfeld DK. Limited fine hand use after stroke and its association with other disabilities. J Rehabil Med (2008) 40:603-8. doi:10.2340/16501977-0218

194. Baztán JJ, Gálvez CP, Soccoro A. Reocvery of functional impairment after acute illness and mortality: one-year follow-up study. Gerontology (2009) 55:269-74. doi:10.1159/000193068

195. Gosselin S, Desrosiers J, Corriveau H, Hébert R, Rochette A, Provencher $\mathrm{V}$, et al. Outcomes during and after inpatient rehabilitation: comparison between adults and older adults. J Rehabil Med (2008) 40:55-60. doi:10.2340/16501977-0144

196. Kwakkel G, Wagenaar RC, TwiskJW, Lankhorst GJ, Koetsier JC. Intensity ofleg and arm training after primary middle-cerebral-artery stroke: a randomised trial. Lancet (1999) 354:191-6. doi:10.1016/S0140-6736(98)09477-X

197. Takahashi CD, Der-Yeghiaian L, Le V, Motiwala RR, Cramer SC. Robot-based hand motor therapy after stroke. Brain (2008) 131:425-37. doi:10.1093/ brain/awm311

198. Luft AR, Macko RF, Forrester LW, Villagra F, Ivey F, Sorkin JD, et al. Treadmill exercise activates subcortical neural networks and improves walking after stroke: a randomized controlled trial. Stroke (2008) 39:3341-50. doi:10.1161/ STROKEAHA.108.527531

199. Lindberg PG, Schmitz C, Engardt M, Forssberg H, Borg J. Use-dependent up- and down-regulation of sensorimotor brain circuits in stroke patients. NeurorehabilNeuralRepair(2007)21:315-26.doi:10.1177/1545968306296965

200. Dong Y, Winstein CJ, Albestegui-DuBois R, Dobkin BH. Evolution of fMRI activation in the perilesional primary motor cortex and cerebellum with rehabilitation training-related motor gains after stroke: a pilot study. Neurorehabil Neural Repair (2007) 21:412-28. doi:10.1177/1545968306298598

201. Mintzopoulos D, Khanicheh A, Konstas AA, Astrakas LG, Singhal AB, Moskowitz MA, et al. Functional MRI of rehabilitation in chronic stroke patients using novel MR-compatible hand robotics. Open Neuroimag J (2008) 2:94-101. doi:10.2174/1874440000802010094

202. Yavuzer G, Selles R, Sezer N, Sütbeyaz S, Bussmann JB, Köseoğlu F, et al. Mirror therapy improves hand function in subacute stroke: a randomized controlled trial. Arch Phys Med Rehabil (2008) 89:393-8. doi:10.1016/j. apmr.2007.08.162

203. DohleC, Püllen J, Nakaten A, KüstJ, RietzC, KarbeH. Mirror therapy promotes recovery from severe hemiparesis: a randomized controlled trial. Neurorehabil Neural Repair (2009) 23:209-17. doi:10.1177/1545968308324786

204. Mudie MH, Matyas TA. Responses of the densely hemiplegic upper extremity to bilateral training. Neurorehabil Neural Repair (2001) 15:129-40. doi:10.1177/154596830101500206

205. Perez MA, Cohen LG. Mechanisms underlying functional changes in the primary motor cortex ipsilateral to an active hand. J Neurosci (2008) 28:5631-40. doi:10.1523/JNEUROSCI.0093-08.2008
206. Wolf SL, LeCraw DE, Barton LA, Jann BB. Forced use of hemiplegic upper extremities to reverse the effect of learned nonuse among chronic stroke and head-injured patients. Exp Neurol (1989) 104:125-32. doi:10.1016/ S0014-4886(89)80005-6

207. Taub E, Uswatte G, Pidikiti R. Constraint-induced movement therapy: a new family of techniques with broad application to physical rehabilitation - a clinical review. J Rehabil Res Dev (1999) 36:237-51.

208. Liepert J, Miltner WH, Bauder H, Sommer M, Dettmers C, Taub E, et al. Motor cortex plasticity during constraint-induced movement therapy in stroke patients. Neurosci Lett (1998) 250:5-8. doi:10.1016/ S0304-3940(98)00386-3

209. Sawaki L, Butler AJ, Leng X, Wassenaar PA, Mohammad YM, Blanton S, et al. Constraint-induced movement therapy results in increased motor map area in subjects 3 to 9 months after stroke. Neurorehabil Neural Repair (2008) 22:505-13. doi: $10.1177 / 1545968308317531$

210. Gauthier LV, Taub E, Perkins C, Ortmann M, Mark UW, Uswatte G. Remodelling the brain: plastic structural brain changes produced by different motor therapies after stroke. Stroke (2008) 39:1520-5. doi:10.1161/ STROKEAHA.107.502229

211. Cameirao MS, Bermudez IBS, Duarte E, Verschure PF. Virtual reality based rehabilitation speeds up functional recovery of the upper extremities after stroke: a randomized controlled pilot study in the acute phase of stroke using the rehabilitation gaming system. Restor Neurol Neurosci (2011) 29:287-98. doi:10.3233/RNN-2011-0599

212. Prochnow D, Bermúdez i Badia S, Schmidt J, Duff A, Brunheim S, Kleiser $\mathrm{R}$, et al. An fMRI study of visuomotor processing in a virtual reality based paradigm: rehabilitation gaming system. Eur J Neurosci (2013) 37:1441-7. doi:10.1111/ejn.12157

213. Seitz RJ, Kammerzell A, Samartzi M. Monitoring of visuomotor coordination in healthy subjects and patients with stroke and Parkinson's disease: an application study using the PABLO-device. Int J Neurorehab (2014) 1:113. doi:10.4172/ijn.1000113

214. Ertelt D, Small S, Solodkin A, Dettmers C, McNamara A, Binkofski F, et al. Action observation has a positive impact on rehabilitation of motor deficits after stroke. Neuroimage (2007) 36(Suppl 2):T164-73. doi:10.1016/j. neuroimage.2007.03.043

Conflict of Interest Statement: The authors declare that the research was conducted in the absence of any commercial or financial relationships that could be construed as a potential conflict of interest.

Copyright (C) 2015 Seitz and Donnan. This is an open-access article distributed under the terms of the Creative Commons Attribution License (CC BY). The use, distribution or reproduction in other forums is permitted, provided the original author(s) or licensor are credited and that the original publication in this journal is cited, in accordance with accepted academic practice. No use, distribution or reproduction is permitted which does not comply with these terms. 